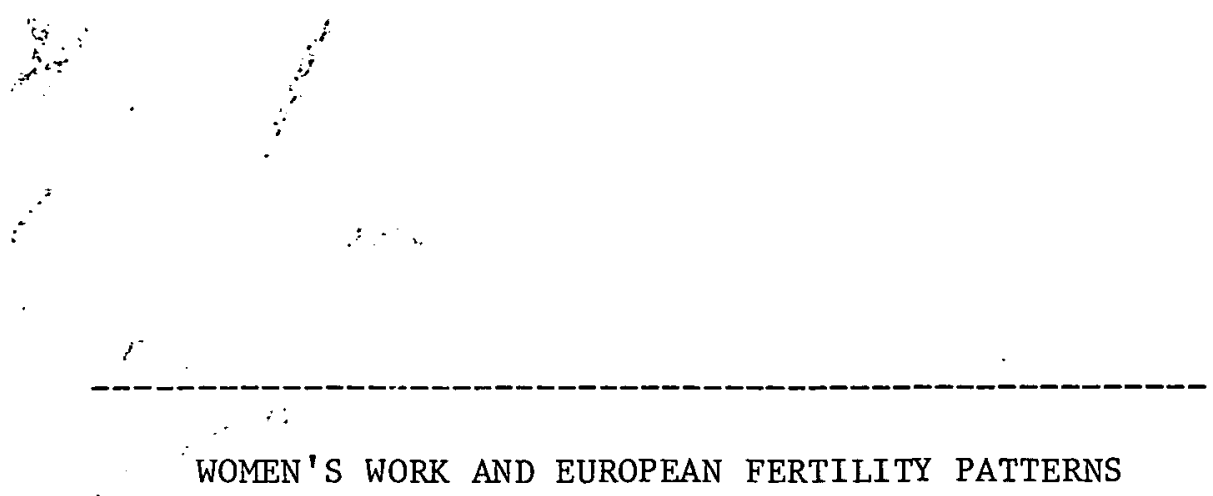

Louise A. Tilly

Michigan State University

Joan W. Scott

Northwestern University

Miriam Cohen

University of Michigan

March, 1974

CRSO Working Paper \#⿰氵5

Copies available through:

Center for Research

on Social Organization

University of Michigan

$4001^{\circ}$ LSA Building

Ann Arbor, Michigan

$48109-1382$ 


\section{WOMEN'S WORK AND EUROPEAN FERTILITY PATTERNS}

Louise A. Tilly Michigan state University
Joan W. Scott Northwestern University
Miriam Cohen University of Michigan

March, 1974 
During the nineteenth century most commentators on the "condition of the working classes" attributed large families and frequent illegitimacy among the poor to social, economic or moral pathology. For Engels overpopulated working class families were the offspring of industrial capitalism. For Malthus, they were evidence of imprudence, of an inability to make rational calculations. For both, as for many government investigators and social reformers, high rates of fertility among married and single workers were both indicators and causes of misery and deprivation. Since the nineteenth century, of course, there have been many debates about the effects of industrialization on the standard of living of workers and on their demographic behavior. There have been some studies of family size among occupational groups and there have been attempts to describe and explain changes in working class fertility patterns. Most of these studies lack the explicit moralizing of the l9th century commentators, although some implicitly retain those biases. Few, however, maintain that large families and numerous bastards were positive developments. 1 
Now Edward Shorter, in his recent article, "Female Emancipation, Birth Control and Fertility in European History," advances such an argument. In an intriguing and provocative piece, Shorter speculated that "female emancipation" led to increased rates of legitimate and illegitimate fertility in Western Europe at the end of the 18th century. His subject is not economic deprivation; indeed that is an irrelevant consideration for him. Instead, he maintains that industrialization early led to the sexual emancipation of working class women by offering employment opportunities for them outside the home. Work led to sexual liberation, according to shorter, by revolutionizing women's attitudes about themselves. They became individualistic and self-seeking. They rebelled against traditional constraints and sought pleasure and fulfillment in uninhibited sexual activity. In the absence of birth control, heightened sexual activity inevitably meant more children. Indeed, towards the end of the nineteenth century, as information about contraception became available, fertility rates sharply declined.2

Shorter's is a novel interpretation with some important contributions to women's history as well as to demographic history. Above all, shorter must be commended for bringing together hitherto scattered evidence about European fertility patterns. He has clearly established that from about 1750-90 increases in illegitimate fertility rates paralleled increases in legitimate fertility rates in much of Western Europe. At the end of the nineteenth century both rates show a parallel decline. In addition, shorter insists that the social and economic experience of women is central to fertility changes. 
In so doing he implicitly challenges the conventional view of women's history which sees political emancipation as the source of all other changes in women's lives in the modern world. This view, which echoes some of the more simplistic literature on political development, suggests that a change in political consciousness during the nineteenth century led to political enfranchisement for women in the twentieth century, and only then to their expanded social and economic activity. Shorter, on the contrary, points out the social, economic and demographic changes in women's lives that pre-dated political emancipation by more than 100 years.

Dèspite these contributions, however, Shorter's article is misleading. It confuses the connections between fertility patterns and women's experience instead of clarifying them. If Shorter accurately describes changes in fertility, he nonetheless explains them incorrectly. And while he is justified in insisting that women's history must be considered by historical demographers, he fails to seriously examine that history. Instead he accepts without examination the conventional notion that women in pre-industrial society were subordinate and powerless. And he proceeds to incorporate this notion into his model. The key to rising fertility, for shorter, is a change in popular mentality, particularly in the attitudes of women. This change logically follows, he asserts, from women's exposure to "the values of the marketplace," when they work outside the home. Work for pay makes them more independent and less powerless. Their new values lead unquestionably to a "genuine change in popular sexual behavior." 
The clarity and simplicity of shorter's logic may be persuasive, yet the historical evidence he offers is scant. Historians previous efforts to explain large-scale social change in terms of altered mentalities have been notably unpersuasive. Shorter's attempt fails, too, because he gives no direct evidence for a change in attitude. In fact, Shorter's evidence that attitudes changed is only the consequence of that presumed change. In other words, increased fertility rates are the only real proof he has that women's attitudes and sexual behavior did change. There is, despite Shorter's neglect of it, a growing body of historical evidence about woman's role in pre-industrial and industrial society. It seriously questions both Shorter's premise about the position of pre-industrial women and his central assertion that a change in popular attitudes increased legitimate and illegitimate fertility. Examination of that evidence leads us to reject Shorter's explanation of the fertility changes he describes. His model may be elegant and symmetrical, but it is also ahistorical and profoundly inaccurate.

In this article we will first examine shorter's hypothesis in some detail. Then we will present the historical evidence about women's work experiences before and during industrialization. Finally, we will offer an alternative model to explain fertility changes which is based on that evidence.

\section{Shorter's hypothesis}

When Shorter began writing about illegitimacy, he attributed its increase between 1790 and 1860 to a sexual revolution. But he carefully related sexual behavior to social situations. Social 
instability, he suggested, would tend to decrease the likelihood that marriage would follow a sexual encounter; while in stable social situations, marriage more regularly legitimized sexual relationships. The model he constructed was a more complicated one than we have described and we have serious disagreements with it; but it is unnecessary in this article to review it at length. The important point is that in his earlier work, Shorter indicated that sexual relationships and marriage patterns (and hence fertility rates) were extremely sensitive to a complex of social and economic realities and to changes in them. 3

In his more recent piece, shorter has sharpened and simplified the argument. He builds his case by correlating a number of events: industrialization, migration, changes in women's work, changes in fertility rates, etc. He then argues that since they all have to do with fertility, they can be reduced to a single causal sequence. That causal sequence is constructed on a premise about a change in women's attitudes. Structural considerations are pushed aside, so are alternative explanations. According to Shorter, a change in fertility rates can only mean a change in sexual practices, which has to mean a change in attitudes, particularly of women. The sequence must be linear and direct. Shorter assumes that legitimate and illegitimate fertility rates rose after 1750 because newly "emancipated" single and married women engaged in more frequent sexual intercourse in a quest for sexual fulfillment. Their emancipation came from their contact with the market economy. 
It seems a plausible proposition that people assimilate in the market place an integrated, coherent set of values about social behavior and personal independence and that these values quickly inform the noneconomic realm of individual mentalities. If this logic holds true, we may identify exposure to the market place as a prime source of female emancipation. 4

This statement, as its language clearly reveàls, is based on a chain of reasoning, not on historical evidence. Shorter offers no evidence to prove that more women did work in the capitalist market place in this period. He merely assumes that they did. Similarly, he assumes that women at the end of the eighteenth century had different family roles and attitudes from their predecessors. And he assumes as well that changes in work opportunities inevitably changed values. 5 Ideas, in his opinion, immediately reflect one's current economic experience. Thus for Shorter, a mechanistic notion of "value transfer" bridges the gap between changes in occupational structure and:in collective mentalities. "In the eighteenth and early nineteenth centuries the market economy encroached steadily at the cost of the moral economy, and the values of individual self-interest and competitiveness that people learned in the market were soon transferred to other areas of life." 6

Shorter has sexual behavior echoing market behavior at every point. "Emancipated" women have gained a sense of autonomy at work that the subordinate and powerless women of pre-industrial society lacked. That work, created as it was by capitalist economic development, necessarily fostered values of individualism in those who participated in it. Individualism was expressed in part by a new desire for sexual gratification. Young women working 
outside the home, Shorter insists, were by definition rebelling against parental authority. Indeed, they sought work in order to gain independence and individual fulfillment that could not be attained at home. It follows, in shorter's logic, that sexual behavior, too, must have been defiant of parental restraint. As the market economy spread there arose a new libertine proletarian subculture, "indulgent of eroticism." Once married, the independent young working women engaged in frequent intercourse because they and their husbands took greater pleasure in sex and put more value on companionship than had their traditional counterparts. Female "emancipation" thus began among the young and poor. In the absence of birth control, the sexual gratification of single working girls increased the illegitimate birth rate; that of married working women inflated the legitimate birth rate. In this fashion Shorter answers a central question of European historical demography. The fertility increase in the late eighteenth century was simply the result of the "emancipation', occupational and sexual, of working class women.

Shorter then attributes the fall in fertility at the end of the nineteenth century to the diffusion of birth control knowledge and techniques. Middle class women were the first to use birth control. Later, it was adopted as well by lower class women, "mentally prepared for small families" by their experiences with motherhood and work. Presumably single lower class women were even more willing to curb their fertility once they knew how. Meanwhile, middle class women became personally emancipated. The chronological coincidence of the search for individual autonomy, which originated among the lower classes, and of techniques 
of birth control, known first to the middle classes, caused the late nineteenth century fertility decline. Shorter concludes by suggesting that the movement for women's political rights was the final outcome of the growth of capitalism, industrialization, and changes in women's work which had started more than a century earlier.

It is now time to examine the historical evidence shorter neglected about woman's role in pre-industrial society; about the effects of industrialization on women's work; and about the motives which sent young girls out into the "marketplace" at the end of the eighteenth and beginning of the nineteenth century. None of the evidence we have found supports Shorter's argument in any way. Women were not powerless and subordinate in "traditional" families; indeed they played important economic roles. Industrialization did not significantly modernize women's work in the period when fertility rates rose; in fact, the vast majority of working women did not work in factories, but at customary women's jobs. Women became wage earners during the early phases of industrialization, not because they were rebelling against their parents, but because they were sent out to work in the service of the family interest. No change in attitude increased the numbers of children working women bore. Rather old attitudes and traditional behavior operating in changed circumstances led to increased illegitimate and legitimate fertility. Women eventually did shed many traditional values, and by the end of the nineteenth century some working women had clearly adopted "modern" life styles. The important point, however, is that the years around 1790 were not a watershed in the history of 
women's economic emancipation--despite the fact that women's work moved outside the home. These were the crucial years for the increases in fertility in Europe. All the evidence is not in;: by any means. The evidence we offer, however, indicates that in this period, the women of the popular classes simply were not undergoing a search for freedom or the experience of emancipation. The explanation for changed fertility patterns lies elsewhere, as we shall demonstrate in the last section of this article.

Women's Place in "Traditional" Families

Historical and ethnographic evidence suggests that the women of the popular classes did not conform to shorter's characterization of them as subordinate, dependent and powerless. On the contrary, in the seventeenth, eighteenth and nineteenth centuries (as in present-day, less- developed areas in Europe) women usually played an important economic role within the family. The "popular classes" of pre-industrial society included people from several different economic categories. In rural areas they ranged from prosperous land-owning peasants to landless laborers who hired out as agricultural hands, domestic servants, or (increasingly from the seventeenth century on) workers in cottage industry. In cities, there were artisans at one end of the spectrum and unskilled workers at the other. In both city and country the lower orders included those with property--peasants and artisans, (the latter owned their tools and conceived of their skills as a form of property)-- and those without it (landless laborers and unskilled urban laborers). Among both types--the propertied and unpropertied--the family was the elementary unit 
of work in pre-industrial Europe. All members of the family, women and children as well as men, contributed to its wellbeing. Women were partners in the enterprise, whether it was a farm, a shop, or the less clearly defined economic unit of the urban poor family.

In the pre-industrial family, the household was organized as a family or domestic economy. Men, women and children worked at tasks which were differentiated by age and sex, but the work of all was necessary for survival. Artisans' wives assisted their husbands in their work as weavers, bakers, shoemakers or tailors. Certain work, like weaving, whether carried on in the city or the country, needed the cooperation of all family members. Children and women did spinning and carding; men ran the looms. Wives also managed many aspects of the household, including family finances. In less prosperous urban families, women did paid work which was often an extension of their household chores. They sewed and made lace. They also took odd jobs, as carters, laundresses and street cleaners. Unmarried women also became servants. Resourcefulness was characteristic of poor women. When they could not find work which would enable them to contribute to the family income, they begged, stole or became prostitutes. Olwen Hufton's work on the Parisian poor in the eighteenth century and Alan Forrest's on Bordeaux both describe the crucial economic contribution of urban working class women and the consequent central role these women played in their families. 7 Although a woman depended on her husband's work for a large measure of the family's support, he in turn could not do without hers.

In the country, the landowning peasants' family was also the 
focus of all economic activity. 8 The members of the family worked together, again at sex-differentiated tasks. Children, boys and girls, were sent to other farms as servants when their help was not needed on the family farm. Their activity, nonetheless, contributed to the well-being of the family. They either sent their earnings home, or, if they were not paid wages, their absence at least relieved the family of the burden of feeding and boarding them. Women's responsibilities included care of the house, barnyard and the dairy. They managed to bring in small profits from marketing of poultry and dairy products and from work in rural domestic industry. Management of the household and particularly of finances led to a central role for women in these families too. An observer in rural Brittany during the nineteenth century reported that the wife and mother of the family made "the important decisions, buying a field, selling a cow, a lawsuit against a neighbor, choice of a future son-in-law." 9 For rural families who did not own land women's work was even more vital. They brought in wages earned in agricultural work, spinning, or petty trading. They contributed their share to the family wage--the only economic resource of the landless family. In city and country, among propertied and propertyless, women of the popular classes had a vital economic role. It is, of course, impossible to guess what sort of sexual relations were practiced under these circumstances. We can say, however, that women were not dependent and powerless in the economic sphere. $^{10}$ Their position in the family was hardly a subordinate one. Hence it is impossible to accept shorter's attempt to deri-ve women'. s 'supposed"sexual subordination from their" place in the' predustrial household. 
Women's Work

What happened in the mid-eighteenth century with the spread of capitalism, the growth of markets, and industrialization? Did these economic changes bring new work experiences for women, with the consequences Shorter describes? Did women, earning money in the capitalist market-place, find a new sense of self that expressed itself in increased sexual activity?

In examining the historical evidence for the effects on women's work of industrialization and urbanization, we find that the location of women's work did change--more young women worked outside the home and in large cities than ever before. But they were recruited from the same groups which had always sent women to work. And they entered occupations which traditionally had employed women. 11

The female labor force of nineteenth century Europe, like that of seventeenth and eighteenth century Europe, consisted primarily of the daughters of the popular classes, secondarily of their wives. The present state of our knowledge makes it difficult to specify precisely the groups within the working classes from which nineteenth century women wage earners came. It is clear, however, that changes in the organization of work must have driven the daughters and wives of craftsmen out of the family shop. Similarly population growth (a result of declining mortality and younger age at marriage due to opportunities for work in cottage industry) created a surplus of hands within theeurban household and on the family farm. Women in these families always had been expected to work. Increasingly they were sent away from home to earn their portion of the family wage. 
The daughters (and sometimes the wives) of the popular classes performed traditional types of women's work during most of the nineteenth century. Domestic service, garment-making, and textiles had long been the chief non-agricultural employers of women. This continued to be the case during the nineteenth century. In France, in 1866 , $69 \%$ of working women outside agriculture were employed in these three fields; in 1896, the percentage was 59\%. ${ }^{12}$ In England, the occupational opportunities for women were similarly stable. In the 1840's, Ivy Pinchbeck, notes, women served in traditional female occupations--the largest percentage were in domestic service, the next largest in textiles, the next in clothing making. In her study of women in the labor force in 1915, B.L. Hutchins noted that as late as 1911, twothirds of working women were in the same three fields: domestic service (including laundry) 35\%; textiles, 19.5\%; garment making $15.6 \% .13$

It is worthwhile to examine the case of England more closely. England was the first country to industrialize. Its fertility rates rose as the country industrialized. Yet contrary to shorter's assumption that new work experiences for women led to increased fertility rates, there is no evidence to indicate that women's work changed significantly at all. During the early phases of British industrialization the proportion of women entering the work-force did not increase. Niether did women work in factories in significant numbers in the crucial late eighteenth century period when fertility rates began to rise.

Aggregate statistics on the number of women workers before 1841 do not exist, but several studies have shown that opportunities 
for women to participate in the economy actually shrank with early industrialization. The reorganization of agriculture displaced women who had worked on the family plot. (A portion of these women did become wage laborers towards the end of the eighteenth century, but only temporarily. Their numbers declined towards the middle of the nineteenth century as did all employment in agriculture.) In the manufacturing sector, the mechanization of cotton spinning first deprived women of that age-old occupation at the end of the eighteenth century. Until the second decade of the next century, women had to compete with children for jobs assisting men, who operated the large new machines. It was not until after the power loom was introduced into the factory (after 1820) that opportunities were created for large numbers of women to participate in the factory work force. ${ }^{14}$ The experience of wool workers was similar. As the industry was concentrated into workshops, long before power driven machinery was introduced, women were excluded from the preparation process. Although some women competed with men as handloom weavers in the early nineteenth century, it was not until the 1860 's that the power loom brought many women into the wool factories. Because the mill-based woolen industry was concentrated in Yorkshire and Nottinghamshire, many female domestic wool workers elsewhere were left permanently unemployed. 15 Finally, as a consequence of changes in the organization of craft work, many artisans' wives who had heretofore taken an active part in their husbands' work were deprived of their occupations.

of course, not all women employed in manufacturing were engaged in textile spinning and weaving. Women's occupations also 
included millinery, corset, boot and shoe-making, dress and artificial flower-making, book binding, food production and canning, and match-making." Such were the industries which employed women primarily in London and other cities. In Birmingham, an unusual number of women engaged in small metal trades. In the course of the nineteenth century, many of these activities were moved into small workshops and larger factories, but this happened long after the factory organization of textile production. 16 Thus itwwas: primarily in the textile industry, and then only after the 1820's that the number of women factoryrworkersaincreased...rAsherormthet impact of early industrialízation on women's work, Ivy Pinchbeck concluded that:

The industrial revolution [in the period 1750-1850]. enormously increased the employment opportunity for. men by new developments in mining, engineering; transportation and the expansion of other industries but there was no corresponding increase for women except in this sphere [as textile operatives]; in other directions, their opportunites had actually declined. 17 .

In England women moved very slowly into "modern occupations". Let us compare the number of women in the British population from 1841-1911, the number of women in the labor force outside agriculture as a whole, and the number of women who were occupied in work other than domestic service. Our proxy for modern occupations, it should be noted," is a rough one, including all non-servant non-agricultural occupations. This includes not only factory jobs, but all manufacturing jobs, in whatever kind of setting, and. non-manufacturing jobs, such as those in commerce and the professions, but excludes agriculture. The following facts are evident. First of all, the munber of women in the labor force outside 


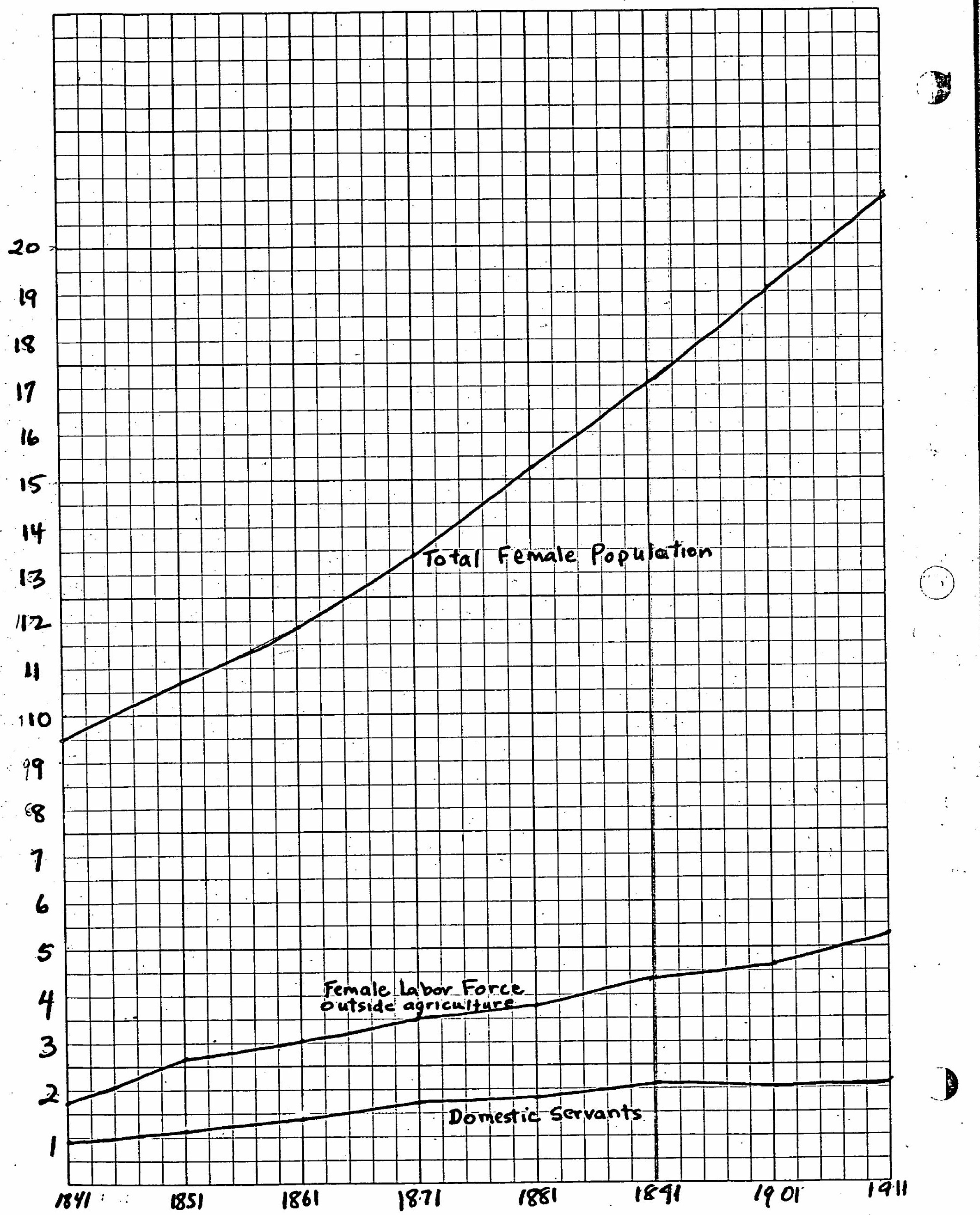


agriculture at the middle of the nineteenth century was relatively small (24.4\%); the non-agricultural female work force did not increase as quickly as the female population grew after mid-century. The largest proportion of women were, in 1841, and remained so in 1891, engaged in domestic and other personal service occupations such as laundry. There was an increase in non-servant occupations between 1841 and 1851 but between 1861 and 1891, servants increased at approximately the same rate as all other occupations. Up to 1891, the growth in modern occupations absorbed neither the natural increase in the female population nor the increase of unemployed females which, as noted above, resulted from structural changes in industry and ägriculture. Inßmid-nineteenthncentưry̌ Engliand a century after shorter's supposed revolution in women's work experience, a large proportion of working women were still in domestic service, and most others were still engaged in traditionallyorganized industries. (In addition there was a substantial increase in women's employment in commerce and professions; in 1911; 500, 000 women were employed in this sector.) Throughout the greater part of the nineteenth century, women's factory work was almost exclusively in textiles, and the number of women employed in factories was a small proportion of the entire female work force.

In cities alone, matters were no different. Urban women remained in traditional occupations. Domestic service persisted as the most important occupation. In 1891, one third of all working women were domestic servants. In 1910, the London county council reported a similar proportion. The next largest occupation was dressmaking, then laundering and tailoring. of the manufacturing 
enterprises, many were still domestic endeavors. A report on women's employment in Birmingham based on the 1901 census showed a relatively high proportion of women in the labor force: $37 \%$. Of these, almost half were engaged either in domestic service, charring, professions or commerce. This meant that even in this manufacturing city, about $20 \%$ of women were employed in industry, with about half that number still in domestic outwork. 18

Shorter's notion that the development of modern capitalism brought new kinds of work opportunities to working class women as early as the middle of the eighteenth century is wrong. It is true that there was a very important change in the location of their work: many rural women were drawn into cities to work; many women worked outside their own homes. This did not revolutionize the occupational structure of working women. Throughout the nineteenth century, traditional occupations continued to dominate women's employment. By the end of the century, factory employment was still minimal.

Shorter is also incorrect in his assumption that the working woman was able to live her life independent of her family because she had the economic means to do so. Evidence for British working women indicates that this was not the case. Throughout the nineteenth century, British working women's wages were considered supplementary incomes, supplementary that is to the wages of other family members. It was assumed by employers that women, unlike men, were not completely responsible for earning their own living. Female wages were always far lower than male. In the Lancashire cotton mills in 1833, where female wages were the highest in the country, females aged 16 to 21 earned $7 \mathrm{~s} 3.5 \mathrm{~d}$ weekly, while males earned 10s 3d. Even larger 
differentials obtained among older workers. In London in the 1880's, there was a similar differential between the average earnings of the sexes. Seventy-two percent of the males in the bookbinding industry earned over $30 \mathrm{~s}$ weekly; $42.5 \%$ of the women made less than $12 \mathrm{~s}$. In precious metals, clocks and watch manufacturing, $83.5 \%$ of the males earned $30 \mathrm{~s}$ or more weekly, females earned 9-12 s. Women in small clothing workshops earned 10-12 s weekly, women engaged in outwork in the clothing trades only $4 \mathrm{~s}$ a week. In Birmingham, in 1900, the average weekly wage for working women under twenty-one was $10 \mathrm{~s}$, for men $18 \mathrm{~s}$. Women's work throughout this period, as in the eighteenth century, was for the most part unskilled. Occupations were often seasonal or irregular. Women were often out of work for many weeks and months during the year. ${ }^{19}$ as ityposisible that thereltwerelcmany single women who could enjoy the life of emancipated independence when the majority could not even afford to live adequately on their personal wages?

Finally, throughout the period, British women tended to give up work outside the home when they married. We can cite only a few examples here, based" mostly on age evidence. In 1833, the bulk of women in the Lancashire cotton mills were between the ages of sixteen and twenty-one: In 1841, in six out of seven districts in Lancashire, $75 \%$ of the female labor force in the cotton mills was unmarried. In the woolen mills of the north and in Glouchestershire, $50 \%$ of the working women left the mills after the age of 21 ; of those remaining, few were married. In London in the $1880^{\prime} \mathrm{s}$, the greatest number of women in the female work force were between 15 and 25 years old. In 1911, in all of Great Britain only $9.6 \%$ of the entire married female population was employed. 20 
Among the married women who did work, domestic industry provided occupations for the largest number. In East London in the 1880's, Booth's survey found that most employed married women did homework. In Birmingham, twenty years later, married women were the largest part of the domestic labor force, as indeed married women had been for decades in most countries of Western Europe. 21...Inocontrast.to middle class women, who could afford servarnts, the work experience . for working class wives was neither psychologically nor economically rewarding, except in the sense that it supplemented an inadequate family wage. If these women worked, they were torn between the cares of a mother and those of a worker. It is no wonder they much preferred to stay home and supervise their own families--a preference amply documented by the labor force statistics.

Nothing then about the structure, the wages, or the nature of women's work from 1750 to 1850 (and much later) confirms shorter's speculation that it offered women an opportunity to emancipate themselves from the confines of traditional family arrangements. In the pre-industrial family women had made an important economic contribution; in early industrialization women's work moved out of the home but stayed in traditional fields. Most women worked when they were daughters, contributing their wages to the family needs. Women who worked as wives also worked in the interest of their families.

\section{Why women worked}

Shorter attributes the work of women outside the home after 1750, particularly that of young, single women, to a change in their outlook: a new desire for independence from parental restraints. He 
argues that since seeking work was an individualistic rebellion against traditionalism, sexual behavior, too, was defiant of parental authority. The facts are that daughters of the popular classes were most often sent into service or to work in the city by their families. Their work represented a continuation of practices customary in the family economy. When resources were scarce or hands at home too numerous, children customarily sought work outside. Their work was an extension of the family economy, and they continued to contribute their earnings to the family. 22; work outside, the thome wasybyonosmeans synonymous with freedom, for young women most often sought that work as a means. of better serving the family interest. Industrialization and urbanization created new problems for rural families and generated new opportunities for them as well. In most cases, they strategically adapted their traditional practices to the new context. Thus, daughters sent out to work went farther away from home than had been customary. Most still defined their work in the family interest and, dutifully, sent their wages home. Sometimes arrangements for payment were made between a girl's parents and her employer --money or foodstuffs were delivered directly to the parents. In other cases, the girls themselves regularly sent money home. Commentators observed that the girls considered this a normal arrangement, part of their obligation to the family.

The conditions of migration for young working girls emphasized their ties to family and in many ways limited their independence. In Italy and France, factory dormitories housed female workers, and nuns regulated their behavior and social lives. 23 . Inhthesnèdlertrades in British cities, enterprising women with a little capital turned their 
homes into lodging houses for piece-workers in their employ. And, while these often provided miserable living conditions, they nonetheless offered a household (and rules of conduct) for a young girl. 24 Domestic service, the largest single occupation for women was also the most traditional and most protective of a young girl. She was being sent from one household to another and thus was given a certain security. Chatelain argues that domestic service was a safe form of migration in France for young girls from the country. The girl had a place to live, a family, food, lodging and she need not fend for herself in the unknown big city as soon as she arrived. 25 . Its isrterue that often servants longed to leave their places, and that they chafed under the dictates of their mistresses (and the advances of their masters). But that does not change the fact that, initially, their migration was sponsored by a set of traditional institutions which limited their individual freedom.

In fact, individual freedom did not seem to be at issue either for the daughters of the landed or the landless, although clearly their experiences differed. It seems likely that peasant families maintained closer ties with their daughters, even when the girls worked in distant cities. The family interest in the farm (the property that was the birthright of the linneage and not of any individual) was a powerful influence on individual behavior. Thus farm girls working as domestics continued to send money home. Married daughters working as domestics in Norwegian cities sent their children home to be raised on the farm by grandparents.? But-evenewhen ties ofithis sort were not maintained, it was not from rebellious motives. Rudolf Braun describes the late eighteenth century situation of peasants in the hinterland of Zurich. These peasants were willing to divide their 
holdings for their children because of new work opportunities in cottage industry. These young people married earlier than they would have if the farm had been held undivided, and they quickly establised their own families. Braun suggests that the young workers soon lost touch with their parents. The process, as he describes it however was not a rebellion. Rather the young people went into cottage industry to lessen the burden they represented for the family. 27 These motives were welcomed and encouraged by the parents. Family bonds were stretched and broken, but that was a consequence, not a cause, of the new opportunities for work.

Similarly, among urban artisans, older values informed the adaptation to a new organization of work and to technological change. Initially artisans as well as their political spokesmen insisted that the old values of association and cooperation could continue to characterize their work relationships in the new industrial society. Artisan subculture in cities during the early stages of industrialization was not characterized by an individualistic, self-seeking ideology, as the work of E.P. Thompson, Olwen Hufton, Allan Forrest, Albert Soboul, Remi Gossez and others has clearly shown:28. With no evidence to show that urban artisans adopted the values of the marketplace at work, Shorter's deduction about a "libertine proletarian subculture" has neither factual nor logical validity. It seems more likely that artisan families, like peasant families, sent their wives and daughters to work to help bolster the shaky economic situation of the family. These women undoubtedly joined the ranks of the unskilled women who, for centuries, had constituted the urban female workforce. Wives and daughters of the unskilled and propertyless had worked 
for centuries at service and manufacturing jobs in cities. They did so in the family interest, an interest defined by need rather than by property or skill. Subsistence required a contribution from each family member; everyone depended on everyone else. The women in these families continued to work during the nineteenth century, but there were more of them because the proportions of unskilled propertyles's workers increased. Eighteenth and early nineteenth century cities grew primarily by migration. The urban working class was thus constantly renewed and enlarged by a stream of rural migrants. Agricultural change drove rural laborers and peasants cityward at the end of the eighteenth century, and technological change drove many artisans and their families into the ranks of the unskilled. Women worked outside the home then because they had to. Their attitudes did not necessarily change. On the contrary, structural changes increased the. numbers of women wage earners; ...but. the women themselves were motivated by values long familiar to the women of the popular classes. Family interest and not self-interest was the underlying motive for their work.

The Origins of Increased Illegitimacy

The compositional changes which increased the numbers of unskilled, propertyless workers and raised the proportion of themrin urban populations also contributed to an increase in rates of illegitmacy. Women in this group of the population always had contributed most illegitimate births. A larger number of women in this group, therefore, meant a greater incidence of illegitimate births.

A recent article by Peter Laslett and Karla Oosterveen speaks directly to shorter's speculations: "... The assumption that illegit- 
imacy figures directly reflect the prevalence of sexual intercourse outside marriage, which seems to be made whenever such figures are used to show that beliefis, attitudes and interests have changed in some particular way, can be shown to be very shaky in its foundations." Using data from Colyton, collected and analyzed by E.A. Wrigley, they argue that one important component in the incidence of illegitimacy istthe existence of illegitimacy-prone families, which bring forth bastards generation after generation. Nevertheless, they warn, "this projected sub-society never produced all the bastards, all the bastard-bearers. " 29

Our explanation of urban illegitimacy involves the notion of a sub-culture like the one advanced by Laslett and oosterveen. In this case it is a working class sub-culture in which alternative marriagethe free or consensual union--was common long before the mid-eighteenth century. Unions of this type sometimes preceded legal marriage by a period of years, sometimes they replaced legal marriage for a couple's entire period of cohabitation. The source of the practice was an economic one. Whereas young people from artisan and peasant families insured the transmission of skill and property by marrying legally, the children of the poor had no such resources to protect. Their jobs were their only security, no contract could protect those. Hence, there was no real need for a legal act of marriage. The numbers of free unions increased greatly as unskilled men and women migrated from rural areas to cities. They increased not because the new migrants suddenly adopted the values of a subculture into which they moved, but because the free union was often a practical form of marriage for the urban poor. That it was defined as a 
prelude to or a form of marriage (whether or not it endured) is crucial, for this indicates that traditional expectations motivated the behavior that led to illegitimacy. Not a change in attitude, but a change in context and circumstance, resulted in increased rates of illegitimacy in the late eighteenth and early nineteenth centuries. Let us examine more closely the ways in which young working girls became the mothers of illegitimate children.

A number of pressures impelled young working girls to find mates. One was the loneliness and isolation of work in the city. Another was economic need; wages were low and employment for women was unstable. The logical move for a single girl whose circumstances had taken her far from her family would be to find a husband with whom she might reestablish the family economy, the only viable economic unit she knew. Yet another pressure was the desire to escape the confines of domestic service, the occupation which more and more young women were entering.

Could not this desire to establish a family be what the domestic servants, described by the Munich police chief in 1815, sought? No quest for pleasure is inherent in the fact that "so many young girls leave service... But they do little real work and let themselves be supported by boyfriends; they become pregnant and then are abandoned."30 A sad and distorted version of the traditional family, but an attempt at it nevertheless. Recent work has shown, in fact, that for many French servants in the nineteenth century, this kind of transfer to urban life and an urban husband was sucessful. 31

Was it a search for sexual fulfillment that prompted young women to become "engaged" to young men and then sleep with them in the expectation that marriage would follow? Not at all. In rural and 
urban areas pre-marital sexual relationships were common. 32 The urban subculture was not "indulgent of eroticism"; it merely accepted consensual unions. What shorter interprets as sexual libertinism, as evidence of an individualistic desire for sexual pleasure is more likely an expression of the traditional wish to marry. The attempt to reconstitute the family economy, in the context of economic deprivation and geographic mobility produced these unions.

Consensual unions had two different kinds of consequences for those who entered them; but both resulted in illegitimate children. One consequence, the more stable, was common law marriage, a more or less permanent relationship. The other was less stable and involved desertion of the woman, or a series of short-lived encounters, or prostitution. Middle class observers were most disturbed by the unstable side of consensual union, and especially by the increase in the numbers of abandoned pregnant women and prostitutes.

Many asked how these women let themselves get into difficult and immoral situations. When they asked; the :wömendirectly, whe answer was most freguently that the man promised to marry them. In Nantes, in the eighteenth century, information drawn from women's declarations to midwives at childbirth shows that mothers of illegitimate children were, for the most part, servants and working women. (The fathers were more likely to be from the lower classes only at the end of the century.) These women testified that promises of work and of marriage were usually the prelude to intercourse with the fathers of their bastards. 33 In. Aix in 1787-88, according to Cissie Fairchild, the declarations de grossesse, show that about one-half of the abandoned mothers had been living away from their families when they became pregnant and that the 
vast majority of all illegitimate pregnancies were preceded by promises of marriage. ${ }^{34}$ A needleworker explained her plight to Henry Mayhew in 1851: "He told me if I came to live with him he'd care I. should not want, and both mother and me had been very bad off before. He said, he'd make me his lawful wife..." 35

Marriage failed to take place for many reasons. The absence of the traditional constraints-family, local community and church-led to the disappointment of marital expectations. Lack of money or a lost job, the opportunity for work in a distant city, all kept men from fulfilling their promises. And the woman's family was nowhere at hand to enforce the promise. Eighteenth century evidence from Lillè; also based on women's declarations during childbirth, shows that most unmarried mothers were women who had come to work in the city as textile workers or as servants, all poorly paid occupations. Fully $70 \%$ of these women came from families broken by the death of at least one parent. The men involved were in professions marked by unstable tenure, such as servants, traveling workers or soldiers:. Lottin concludes that work outside the family weakened family authority and "faciliated the emancipation of the girls." But like Shorter, his evidence for this statement is only illegitimate birth statistics. Lottin's other point seems more likely in light of the evidence about the occupations and backrounds of the women he has studied: "All the same, seducers could pursue their ends more easily, because they did not fear an avenging father, often violent, ready to make them pay for the dishonor." 36

Richard Cobb's sympathetic evocation of lower class life during the YeariII of the- French Revolution notes that'".women ind girls born 
in the provinces were easier to recruit to prostitution and were less protected. ("They were also much more exposed to seduction and to unemployment...)...prostitution witnesses for the feminine population as a whole, emphasized its fluidity, its insecurity, the enormous risks encountered by the provincial girl..." In 1836 , in Paris, Parent-Duchatelet reported that the majority of the prostitutes he studied were recent migrants. Almost a third were household servants and maný had been initially seduced by promises of marriage, abandoned pregnant or with an infant. He also remarked on the instability of women's employment which drove them to prostitution when they could not find work. 37. Some years later, and across the channel, abandoned women told Henry Mayhew some of the reasons that their hoped-for marriages never took place: sometimes there was no money for a proper wedding; sometimes the men moved on to search for work; sometimes poverty created unbearable emotional stress. ${ }^{38}$ overâll, the tradional contexts which identified and demanded "proper" behavior were absent. There is obviously much still to be learned about young working girls and about the behavior and motives of their suitors. The central point here is that no major change in values or mentality was necessary to create these cases of illegitimacy. Rather, traditional expectations operating in a changed context, yielded unanticipated (and often unhappy) results.

If they were left with illegitimate children far from their families, young women were forced to become independent. But theirs was an independence or self-reliance based on desperation and disillusionment, not the carefree, self-seekring, individualism of 
Shorter's "wish to' be free." Evidence for this can be found in the reasons for their prostitution given by women in the Year III: "to : get bread," "to be able to live," "to feed my child," "to pay for a wet nurse." These women's lives were miserable and unsettled; they lived here and there, making money as they could. (The Nantes illegitimacy birth declarations also revealed the grim housing conditions in which these births occurred.) "What are we?" exclaimed a Paris prostitute, "Most of us are unfortunate women, without origins, without education, servants, maids for the most part..." 39. These bitter tones are echoed by the London working girls who told Henry Mayhew that they "went wrong" in order to support their children. Prostitution in turn produced more illegitimate children. Many prostitutes were domestic servants or girls from the garment industry out of work--women whose need sent them into the streets. In an ironic way, even this kind of activity had its traditional roots. Hufton's catalog of the resources developed by lower class women in pre-Revolutionary France in their roles as providers of food includes begging, renting out their children to other beggars, flirtation and sexual favors. Many of the girls testifying to Mayhew of their "shame" explained it as the only way to provide food for their children and keep them out of the workhouse. This attitude would have been recognizeable to the peasant woman, although she would have found the life-style associated with it unfamiliar and abhorrent: the woman's body was her last resource in a desparate effort to support her family.

The sheer increase in the numbers of prostitutes and deserted pregnant women was not alone responsible for the increase in ille- 
gitimacy rates. The development of charitable institutions devoted to the care of illegitimate children lengthened the lives of these children or, at least, registered their births. From the midseventeenth century on, reformers, who established new founding hospitals or improved old ones, explicitly defined their goal as the elimination of infanticide. St. Vincent de Paul's work in Paris, for example, culminated in the dedication of the Bicetre for this purpose in 1690. A Foundling Hospital was opened in Dublin in 1704. And, in 1739, the London hospital was incorporated, "to prevent the frequent murders of poor miserable children at their birth, and to suppress the inhuman custom of exposing new-born infants to perish in the streets." Similarly such hospitals were opened in Strasbourg (in 1748) and in Moscow and st. Petersburg during the reign of catherine. Malthus, in fact, criticized the Russian institutions for discouraging maririage by making it too easy for illegitimate children to be cared for by others. ${ }^{40}$. The incidence of infanticide in the sixteenth and seventeenth centuries has never been quantified, as far as we know, but qualitative evidence suggests that death was the common fate of the children of illicit unions, whether the mother was deserted or the parents simply too poor to support another child. The hospitals, of course, often simply institutionalized infanticide, but they guaranteed registration of the birth in hospital baptismal records. The 18th century foundling hospital "civilized" the care of illegitimate children by baptizing them, but it failed in the majority of cases to nurture these children to adulthood.

Prostitutes and deserted women were not the only mothers of 
illegitimate children in the eighteenth and nineteenth centuries. More often, indeed, bastards were the products of stable consensual unions which sometimes even ended as legal marriages. The numbers of these unions increased as the population of unskilled, propertyless workers grew in cities. These unions were not a new phenomenon; instead they represented the continuation of a practice long common in the urban working class milieu. From mid-seventeenth century Aix comes this comment on the urban poor: "They almost never know the sanctity of marriage and live together in shameful fashion. "4l Franklin Ford characterizes mid-eighteenth century strasbourg as "a society where cohabitations frequently began with the formal announcement of intended marriage. This practice did not enjoy full social or religious approval to be sure, but neither did it create any particular scandal." Children born out of wedlock were frequently legitimated by marriage, Ford says, but even when this did not happen, the mother's family recognized its responsibility for her child. ${ }^{42}$. Similar practises were noted by Frederic Le:play in his biographies of urban workers in the middle of the nineteenth century and by novelists of working class life such as Emile Zola. Agulhon also describes the existence of free unions among the working class of Toulon before $1849 .{ }^{43}$. The society of st. Vincent de paul tried to discourage the practice by sponsoring legal marriage. Indeed in Lille workers were said to marry young, but marriage would have been "difficult. for many of. these unfortunates if it had not been for charity coming to their aid." 44 During the commune of 1871 ; according to Edith Thomas, female working class militants insisted that their own custom of free union be written into the radical, anti-clerical 
program of the communards. (Cobb notices, by the way, that many of these militantes had been seduced and deserted at some point in their own lives, and that many came from broken homes or were themselves illegitimate. This suggests that vulnerable women without family ties or protection might be most likely to become involved in free unions themselves. Again, the sub-culture of urban poverty is a perpetuation of traditional practises, not the product of "female liberation" or market-place values.) 45

Free unions increased as more and more young men and women left their native towns and villages and moved to larger towns or cities. For some, there was no point in legalizing a union because there was no property to protect. For others, consensual union was the prelude to marriage, the period during which women worked and accumulated the dowry required for a "proper" marriage. Children born in this period were legitimated at the wedding ceremony. often young people did not marry because they did not know priests or ministers who would marry them. Many, too, scorned the rituals of the church. Others simply were too busy working, and if they were migrants they may well have been ignorant of the place one went to secure a civil act. In some German states, marriage was forbidden to those without sufficient economic resourses. Couples simply lived together without the blessing of the state. 47

Legal sanctification, after all, was not central to the idea of the family among the popular classes. There seems, instead, to have. existed a moral concept of the family similar to the "moral economy" of the popular classes. The moral economy, as E.P. Thompson describes it, involved state-regulated economic relationships, which guaranteed justice and fairness in commercial dealings. There was no state 
interference, of course, in the notion of the "moral family." Instead marriage was based on the consent of the partners and their acceptance of mutual responsibilities. The state regulated public matters such as trade; private matters were left to individuals. especially when no property was involved. Indeed, the common law marriage in England and the consensual union in France were both recognized in law. In France, a witnessed act for marriage in addition to mutual consent of the partners, became law only in the mid-sixteenth century. ${ }^{48}$. It may well be that"although centralizing states and churches imposed legal requirements for marriage, popular traditions continued nonetheless. It is clear that eighteenth century food rioters were guided by notions of a "móral economy", despite the fact that they lived in a market economy. 49 It may also be that these same people held to the idea of the "moral" family, long after church and state insisted that morality included legal sanctification. There is a great deal to be learned about the ideas and practices associated with consensual unions. The important point, however, is that such unions were an old custom which continued into the nineteenth century.

Illegitimacy was the product of free unions, and free unions increased during the late eighteenth and early nineteenth centuries. They increased, in turn, not because personal feelings about sex changed nor because incidences of intercourse increased but because industrialization and urbanization moved many people out of their traditional occupational, social and geographic contexts. Mobility, in fact, was the recurring experience for those people responsible for increased illegitimacy from about 1750 to 1850.50 . Geographic 
mobility meant that men and women left familiar and family setting and therefore lost the protection and constraint they provided. Geographic mobility àlso brought more people into urban working class neighborhoods where marital habits were those of the propertyless. Occupational changes also moved women into vulnerable and economically insecure positions as domestic servants and garment workers in large cities. And occupational changes also account, in part, for the behavior of men in rural as well as urban contexts. Landless laborers, like urban migrants, were often far from their families. They had neither property, nor skill and their jobs were unstable, requiring frequent moves according to season and to harvest schedules. Whether or not women moved along with men, the women were vulnerable to desertion.

Shorter himself describes this kind of situation, in discussing the factors which led to illegitimacy in ruiral areàs. It ilnerant workers seduced young girls and then moved on. "The hapless young girls were still giving the traditional response to what they thought was the customary signal." shorter here acknowledges the traditionalism of the rural women's response, but he insists that the men had changed their attitudes. Again the evidence for this alleged mentality change is the consequence of it--abandoned pregnant women. Without additional evidence we must reject shorter's explanation and insist instead that economic pressures which forced the men to move led them to abandon their girl friends. 51 Rising rates of illegitimacy, then, did not signify a "sexual revolution." They followed, instead, from structural and compositional changes associated with urbanization and industrialization. 
There is no evidence, moreover, that these changes immediately gave rise to changes in attitude. On the contrary, men and women engaged in intercourse with traditional expectations, but in changed or changing contexts. As a result, illegitimacy increased.

\section{A Model for the Rise and Fall of European Fertility Rates}

We have dealt so far with the rise in illegitimate fertility which occurred in most of Europe towards the end of the eighteenth century. Shorter also sees this as the central issue to be explained, but he places it in a much larger context: the rise of all fertility, legitimate and illegitimate in the eighteenth century, and the decline of both kinds of fertility at the end of the nineteenth century. His model is inaccurate and we would like to offer an alternative to it.

We start with declining mortality. Early in the eighteenth century, in much of Western Europe, mortality began to drop, presumably as a result of increased food supply. Subsistence crises ended; and the rate of population growth increased. The growth in population was almost surely distributed differentially by class. The wealthy and the upper levels of the popular classes (propertied peasants and prosperous artisans) experienced reduced adult and child mortality earlier in time than did the poor and unpropertied. As more of the children of these groups survived to adulthood, the problems of "placing" them and of avoiding the fragmentation of property became acute. Thus one source of increased numbers of propertyless people was the surplus children of more prosperous families, who were forced to seek a living with no expectation of inheritance. 
Fortunately, new occupational opportunities were another byproduct of population growth. Increasing population meant increased demand. This, together with a complex of technological and agricultural changes, launched in England the process which became industrialization. But even in England, and a fortiori throughout the rest of Europe, the early effect of increased demand.was the expansion of cottage industry, of market agriculture and of consumer and service industries in administrative and commercial cities. Despite their abundance, however, these jobs often turned out to be quite unstable, as British stocking frame knitters and handloom weavers or French cotton textile workers learned after 1780. In consumer services and domestic service, as in cottage industry, employment fluctuated enormously according to seasons and business cycles.

Far from home, cut off from possible property ownership, and in difficult economic straits, the men and women in cottage, consumer and service industries, acted in what contemporaries called "improvident" ways: they married younger and did not control their fertility as compulsively as peasant and artisan families tended to. 52 The abandonment of late marriage itself meant they had relinquished the chief means used by those families to control fertility. In addition, fertility rose because the young wife had to work. Often the primary cause for the early marriage was the economic need of each partner: subsistence required that they both earn a wage. When married women worked, they nursed their babies a shorter time, if at all. (The extension of the custom of wet-nursing to workers' babies did not indicate the mother's willfül neglect, but the pressing need for her to work). 53 . The reduction of the suckling period decreased the interval between births and increased marital fertility among 
younger couples. Older women, with several children to care for, were less likely to work, hence more likely to nurse. Thus the birth interval was longer later in the family cycle. Yet a third factor in rising marital fertility was infant mortality. In cities, among unstably employed families high rates of infant mortality actually contributed to a reduced interval between births, if the mother had nursed:. When the infant died and the mother stopped nursing, another pregnancy would occur. 54 At least three factors then, contributed to an increase in marital fertility: a drop in the age of marriage, a decline in the numbers of nursing mothers, and an increase in infant mortality among the urban poor. In addition, the numbers of people involved in "inprovident" marriages increased as more people joined the ranks of the propertyless. The economic and physical circumstances of the propertyless in city and country led to an increase in their marital fertility. This increase required no change in attitude. It did require occupational opportunities which economically and physically moved young men and women away from their families of origin and outside of their families' sphere of interest. It also required an economic situation in which couples formed economic units based on the work of both partners. In these circumstances, continuities in sexual customs and unchanged attitudes about sex could bring about radically altered consequences.

Illegitimate fertility also increased because of a growth in the population of propertyless working men and women. Geographic mobility and occupational opportunity meant that the traditional practice of sex before marriage did not always lead to marriage and 
that consensual unions increased in number. In rural areas, geographically mobile men established relationships with women, became betrothed, engaged in intercourse and then moved on. In cities, engagement led to äbandonment, or to a free union. In all cases, illegitimacy was a by-product. The migration of "surplus" children, then, resulted in a larger population of mobile men and of sexually vulnerable women, far from the protection of their families. The consequences of the increase in this population were 1) increased incidence of abandoned pregnant women; 2) increased prostitution of abandoned or unemployed women; 3) increased incidence and duration of consensual or free union. All three of these alternatives produced illegitimate children.

Illegitimate and legitimate fertility rose simultaneously, then, because of a complex of changes stemming from declining mortality during the eighteenth century. These changes increased the numbers of young people physically and materially removed from their families and from work within the traditional household. They were also removed from the constraints on personal and marital behavior of property; for them, the link between marriage and property had been. broken. There is little evidence to indicate, however, that sexual attitudes, particularly those of women, changed. Instead the various attempts at union whether successful or not, represented the pursuit of older goals, an endorsement of traditional male-female relationships. In every kind of situation, the woman's goal, at least, seems to have been to restablish the family economy, the partnership of economic enterprise. These women sought not sexual fulfillment, but economic cooperation. That they often failed to find it, and that 
their attempts to form a family took a variety of forms, does not prove anything about their motivation. The form of male-female relationships was created by social and economic circumstances, not by the sexual attitudes of the partner. And it is those circumstances that must be examined if rising rates of fertility are to be explained.

Why did fertility decline toward the end of the nineteenth century? Above all, because of the increased availability of birth control information. And secondly, because infant mortality declined among the working classes and economic prosperity increased. The explanation offered by James and olive Banks for the decline of middle class fertility applies as well to working class marital fertility. They argue that middle class family size shrank because of the parents' expectations about their own standard of living and because of their rising ambitions for their children.55 Among the working classes, declining infant mortality began to have an impact only towards the end of the nineteenth century. For the first time, the children of working class families were not winnowed drastically by death. At the same time, in most of Europe, educational opportunity became available for the working classes. Finally, the standard of living of workers improved in this period with two important results: 1) many mothers of young children could withdraw from outside work because the family could live on the husband's wages; and 2) children were no longer needed as additional wage earners. With fewer children a man's wages went farther and there would be more money for education of children... (An investment in education was a contribution to a child's future and might function as 
skill and property had earlier.) At this point, it was clearly in the interest of the working class family to limit its fertility. And the means were available to do so. Birth control was adopted by the working class and its martial fertility fell.

What about illegitimate fertility? In an article written with Knodel and Van de Walle, Shorter preemptorially discounts any kind of prosperity model.

It is unlikely that higher incomes moved unwed mothers to curb their illegitimate fertility so as to plan better the educational future of their bastards on hand. Possibly improvements in the standard of living during the last quarter of the nineteenth century restricted illegitimate fertility through some other mechanism. But ad hoc rummaging about for alternate linkages in an 'economic prosperity' model is unlikely to result in any generalizable kind of explanation.

Shorter and his associates assume here that individual decisions-of unwed mothers-- lay behind falling illegitimacy rates. Yet it can be shown that fin-de-siècle prosperity did bring about some compositional changes in European populations which tended to reduce the size of the population which produced illegitimate births. First, the numbers of women in sexually vulnerable situations, particularly servants and other female migrants to cities, began to wane. From about the last decade of the nineteenth century the rate of increase of women in domestic service began to drop; eventually the number of domestic servants absolutely declined. 57 Both the increase in factory jobs for women and the increase in working class prosperity reduced the numbers of women working on their own, far from their families. Second, increased prosperity led to a decrease in the numbers of extremely mobile, propertyless men restlessly moving in search of work. Third, increased prosperity led to a new emphasis on marriage, 
as the urban working classes began to acquire goods and even landed property in working class suburbs. Formal and legalized marriage which spelled out the disposition and use of this property led to a decline in consensual unions. So did the diffusion of middle class personal values to workers, by the efforts of reformers and by educational opportunities for workers' children. Unwed mothers whose illegitimate children were the results of seduction and abandonment or of prostitution might not be able to decide to marry, but couples whose children were equally illegitimate could get to the alter when conventional marriage meant improved opportunity for themselves and their children. Regular employment and better wages clearly opened up new vistas for workers and the custom of free union became less widespread. As middle class values of individualism began to be economically functional for workers, these values informed their economic, órganizational and emotional lives. Working class men and women continued to marry for many kinds of reasons, but love and sentiment began to become more important.

The movement toward the cities, of course, did not end with the nineteenth century. Why did later urbanization and geographic mobility not result in compositional changes like those of the late eighteenth and early nineteenth centuries? First of all, the cities were no longer the same types of administrative and commercial centers with greatest employment opportunity in unstable areas. Industrial growth broadened and changed occupational opportunities in twentieth century cities. Furthermore, most rural migrants to these cities were not as economically vulnerable as their nineteenth century predecessors. They now came from rural areas where fertility was also controlled. Their families thus had greater resources with which to sponsor 
their migration and maintain contacts with them.

In mid-twentieth century Europe, however, there are situations similar to those of the early nineteenth century. Migrants of different racial or national backrounds have employment experiences similar to those of nineteenth century rural migrants. Men's jobs are unstable; women are in low-paying, sexually vulnerable positions as domestics or unskilled service workers. Ironically, the established working-class of these modern European cities is as unsympathetic to the economic claims as was the nineteeth century middle class.

Conclusion

Women's work in the late eighteenth and early nineteenth centuries was not "liberating' in any sense of that term. Women stayed in traditional occupations. They were so poorly paid that economic independence was precluded. Furthermore, they did the work they did as a service for the family interest. The evidence available points to several causes for illegitimacy, none of them related to the "emancipation" of women: physical separation of women from the protection of their families and their economic need; the mobility of men which increased the incidence of marriages manqués (sexual intercourse following a promise of marriage which was never fulfilled,. Finally, analysis of the effects of population growth on propertied peasants and artisans shows that the bifurcation of marriage and property arrangements changed the meaning of marriage for propertyless people and led to increased numbers of men and women living in free unions. Our alternative model has the advantage 
of being built on historical evidence. Much more of this evidence is needed before the model can be confirmed positively. Nevertheless the negative evidence which we have offered for shorter"s model and his own lack of evidence lead us to believe that less sensational but no less dramatic, more complex but less speculative, explanations are in order for the fertility changes in Europe from 1750 to 1900. This examination of the history of working class women and their families in the eighteenth and nineteenth centuries has shown that continuities in mentality mark the fertility rise. The fertility fall, a consequence of the spread of birth control and economic prosperity opened the way for a changed consciousness among women. 58 
NOTES

1. F. Engels, The Condition of the Working class in England in 1844 (London, 1892); Thomas Malthus, First Essay on Population 1798 (reprinted, Ann Arbor, 19 ).

A review of much of the current literature can be found in E. A. Wrigley, Population and History (N. Y. 1969), especially chapters 4 and 5 .

The standard of living controversy is reviewed and commented upon in E. J. Hobsbawm, "The British Standard of Living 1790-1850," in Hobsbawm, ed.. Labouring Men, Essays in the History of Labour (N. Y. 1964). In this connection see also E. P. Thompson, The Making of the English Working Class (London, 1963).

Among specific studies of population are: H. Bergues, and others, La prevention des naissances dans la famille. Ses origines dans les temps modernes (Paris, 1960); K. H. Connell, The population of Ireland 1750-1845 (Oxford, 1950); E. Deniel and L. Henry, "La population d'un village du Nord de la France, Sainghin-en-Melantois, de 1665 à. 1851," Population, 20 (1965),563-602; K. M. Drake, Marriage and Population Growth in Norway 1735-1865 (Cambridge, 1969); H. J. Habakkuk, "Family structure and Economic Change in Nineteenth Century Europe," in N. W. Bell and E. F. Vogel, eds.. A Modern Introduction to the Family (N. Y., 1960); G. Ohlin, "Mortality, Marriage and Growth in Pre-industrial Populations," Population Studies, XIV (1961), 190-197; E. A. Wrigley, Industrial Growth and Population Change (Cambridge, 1961). 
2. Edward Shorter, "Female Emancipation, Birth Control and Fertility in European History," American Historical Review, 78. (June, 1973), 605-640.

3. Edward Shorter, "Illegitimacy, Sexual Revolution and Social Change in Modern Europe," Journal of Interdisciplinary History, II (Autumn, 1971), 237-272. Other articles by Shorter which treat the same question are "Sexual Change and Illegitimacy: The European Experience," in Robert J. Bezucha, ed., Modern European Social History (Lexington, Mass., 1972) and "Capitalism, Culture and sexuality: Some Competing Models," Social Science Quarterly, (September, 1972), 338-356. See älso Shorter, John Knodel and Etienne Van de Walle, "The Decline of Non-Marital Fertility in Europe, 1880-1940," Population Studies, 25 (1971), 375-393. It should be noted that Shorter's various statements of the problem are not all equally speculative or equally insistent on the central role of mentality change. In particular, the article with the demographers Knodel and Van de Walle is much more restrained than later statements, and cearly spells out the intervening variables between intercourse and illegitimate births which shorter later brushes aside, ignores, or argues are insufficient explanations to account for fertility changes.

4. "Female Emancipation, Birth Control and Fertility," 622.

5. The weakness of Shorter's evidence on these points is striking. The source of his description of peasant and working class women's roles in traditional society is 
Moller's study of the eighteenth century petty bourgeois family in Germany. For his proposition about the free and easy sexuality of the early nineteenth century European working class, shorter draws his evidence from post-World War II West Germany. The evidence for changed family relationships rising out of new sexual attitudes is based on evidence and conclusions of other scholars whose interpretations are either twisted by shorter or inapplicable. Furthermore much of this evidence is both logically and chronologically inappropriate. It is 1) Neil Smelser's description of "the reversal of traditional age and sex roles as women and children went into the factory;" 2) Peter Stearns' perception in late nineteenth century ("inconveniently late") Britain of a new independence for working class women; 3) Rudolf Braun's description of the inability to cook of nineteenth century women factory workers. In addition, shorter (while recognizing its limitations) offers the testimony of mid-nineteenth century Bavarian middle class observers who saw in the mores of the popular classes a rebellion of young unmarried women against parental and social authority. "Female Emancipation, Birth Control and Fertility," 615-617.

6. Ibid, 621 .

7. Olwen Hufton, "Women in Revolution, 1789-1796," Past and Present, 53 (1971), 93; Alan Forrest, "The Condition of the Poor in Revolutionary Bordeaux," Past and Present, 59 (1973), 151-152. See also Natalie Z. Davis, "City 
Women and Religious Change in Sixteenth-Century France," in Dorothy Gies McGuigan, ed., A Sampler of Women's

Studies, (Ann Arbor, Michigan, 1973), 21-22, and Michael

Anderson, Family Structure in Nineteenth Century Lancashire, (Cambridge, 1971), 96.

8. On the family basis of the peasant economy see Daniel Thorner, Basile Kerblay and R.E.F. Smith, eds., A. V. Chayanov on the Theory of Peasant Economy, (Homewood, I11., 1966), 21, 60; Teodor Shanin, "The Peasantry as a Political Factor," in Idem.., ed.. Peasants and Peasant Societies: Selected Readings (Penguin Books, 1971), 241-244; Basile Kerblay, "Chayanov and the Theory of Peasantry as a Specific Type of Economy," in Ibid., 151. For Western Europe see Giunta per la Inchiesta Agraria e sulle condizioni della classe agricola, Atti, (Rome, 1882), passim.; Y. Brekilien, La Vie Quotdienne des paysans en Bretagne au XIXe siecle, (Paris, 1966); Henri Mendras, The Vanishing Peasant. Innovation and Change in French Agriculture, (Cambridge, Mass.. 19 ), 74-76; Jean-Marie Gouesse, "Parente, famille et mariage en Normandie aux XVIIe et XVIIIesiecles," Annales. Economies, Societés, Civilisations, 27e Annee (July-October, 1972), 1146-1147 and Annexe V, 1153-1154; Martin Nadaud, Memoires de Leonard, ancien garcon macon (Paris, 1895, reissued, 1948), 130; Michael Drake, Population and Society in Norway, 17351865, (Cambridge, 1969), 137-144, including long quotes from Eilert sundt, on Marriage in Norway. 
9. Brekilien, 69.

10. On this point see Eileen Power, "The Position of Women," in Susan G. Bell, ed., Women: From the Greeks to the French Revolution (Belmont, California, 1973), 166.

11. For an elaboration of this see Joan W. Scott and Louise A. Tilly, "Women's Work and the Family in Nineteenth Century Europe," unpublished paper, 1973.

12. T. Deldycke, H. Gelders, and J.-M. Limbor, La Population active et sa structure, prepared under the supervision of P. Bairoch, (Brussels, 1969), 169.

13. Ivy Pinchbeck, Women Workers and the Industrial Revolution, 1750-1850 (New York, 1930), 84. Similar distributions can be found in Germany and Italy. See Adna Ferrin Weber, The Growth of Cities in the Nineteenth Century (New York, 1967), 375; and Louise A. Tilly, "Women at Work in Milan, Italy, 1880-World War I," unpublished paper read to the American Historical Association, December, 1972.

14. Pinchbeck, op. cit., 117, 152-153; Neil Smelser, Social Change in the Industrial Revolution: An Application of Theory to the British Cotton Industry (Chicago, 1959), 184 and ff.

15. Pinchbeck, , 121, - $155=156$.

16. Edward Cadbury, M. Cecile Matheson and George Shann, Women's Work and Wages: A Phase of Life in An Industrial City, (Chicago, 1907), 44-46, and Gareth Stedman Jones, Outcast London (Oxford, 1971), 83-87.

17. Pinchbeck, 315 . 
18. Cadbury, Matheson, Shann, 44-45.

19. Pinchbeck, 193 (quoted from the Factory Commission, 1834, XIX, 33), Charles Booth, Life and Labour of the People of London (London, New York, 1895), IV, "Population Classified by Trades," passim., Cadbury, Matheson and Shann, 121, Stedman Jones, 83-87.

20. Pinchbeck, 219, Booth, IX, 52, Deldycke, et al., 185.

21. Booth, I, passim. Cadbury, Matheson and Shann, 14.

22. Scott and Tilly, op. cit. See also Rudolf Braun, "The Impact of Cottage Industry on an Agricultural Population," in David Landes, ed., The Rise of Capitalism (New York, 1966), 6l-63; R. -H. Hubscher, "Une contribution à la connaissance des milieux populaires ruraux au XIXe siècle: Le livre de compte de la famille Flauhaut, 1881-1877," Revue d'histoire economique et sociale, 47, (1969), 395-396; Evelyne Sullerot, Histoire et sociologie du travail feminin (Paris, 1968), 91-94; Anderson, 22; Peter Stearns, "Working class Women in Britain, 1890-1914," in Martha Vicinus, ed., Suffer and Be Still (Bloomington, Ind., 1972), 110; Marie Hall Ets, Rosa, The Life of an Italian Immigrant (Minneapolis, 1970), 138-140; Frederic Le Play, Les Ouvriers Europeens, V, 122; Drake, 138; Anderson, 22; for American comparisons, see Robert Smuts, Women and Work in America (New York, 1959), 9. 23. Ets, 87-115; Italy, Ufficio del Lavoro, Rapporti sulla ispezione del lavoro (1 dicembre 1906-30 giugno, 1908), Pubblicazioni del Ufficio del Lavoro, Serie C, 1909, 93-94; Sullerot, 91-94. 
24. Eileen Yeo and E. P. Thompson, The Unknown Mayhem (New York, 1972), 116-180; Sullerot, 100.

25. Abel Chatelain, "Migrations et domesticite feminine urbaine en France, VIIIe siecle-XXe siecle," Revue d'histoire economique et sociale, 47 (1969), 508 .

26. Drake, 138.

27. Braun, 63-64.

28. Thompson, Hufton, Forrest, op. cit.; Albert Soboul, Les Sans-Culottes parisiens en l'an II. (Paris, 1958); Remi Gossez, Les Ouvriers de Paris, Vol. I (Paris, 1967).

29. Peter Laslett and Karla Oosterveen, "Long-term Trends in Bastardy in England. A Study of the Illegitimacy Figures in the Parish Registers and in the Reports of the Registrar General, 1561-1960," Population Studies, 27 (July, 1973), $257-8,284$.

30. Quoted in Shorter, "Female Emancipation, Birth Control and Fertility," 618. Sex ratios discussed in Weber, 285-300, $320,325-327$. Weber also shows that cities in which there were opportunities for women to work had higher nuptuality.

31. Theresa McBride, "Rural Tradition and the Process of Modernization: Domestic Servants in Nineteenth Century France," unpublished doctoral dissertation, Rutgers University, 1973.

32. Shorter, Knodel, Van de Walle, 384, citing wikman on peasant bundling customs. Le Play, Vol. V, 150-154.

33. Shorter, "Sexual Revolution and Social Change," 258; Jacques DePauw, "Amour illegitime et societe a Nantes au 
XVIIIe siècle," Annales. E.S.C., 27e annee (July-October, 1972), 1163-1166. It should be noted that DePauw (1176) finds stable couples rare. Given the circulation of migrants described by Agulhon (see below, note 43) this is not surprising. Even if couples were stable, they were likely to be geographically mobile.

34. Cissie Catherine Fairchilds, "Poverty and Charity in Aixen-Provence, 1640-1789," unpublished doctoral dissertation, Johns Hopkins University, 1972.

35. Yeo and Thompson, 148.

36. Alain Lottin, "Naissances Illegitimies et filles-mères à Lille au XVIIIe siecle," Revue d'histoire moderne et contemporāine,XVII (1970), 309.

37. Richard Cobb, The Police and the People. French Popular Protest 1789-1820. (Oxford, 1970), 235, 238; Alexandre ParentDuchatelet, De la prostitution dans la Ville De Paris (Paris, 1836), 73-75, 93-94. Duchatelet also notes that most women who were prostitutes either had lost their parents, or had been abandoned by their families, or had been expelled from their homes. One-quarter of the women were themselves illegitimate in the period 1828-1832. Vo1. I, 107.

38. Yeo and Thompson, 116-180; see also Massimo Livi Bacci, A Century of Portuguese Fertility (Princeton, 1971), 71-73, cited by Shorter, Knodel and Van de Walle, 382.

39. Cobb, 234, 237, 238. 
40. Encyclopedia Britannica, 1911 edition, Vol. X, 7746-747, "Foundling hospitals;" Franklin Ford, strasbourg in Transition (New York, 1966), 177-179. The graph of illegitimacy in Paris supplied by shorter, "Sexual Revolution and Social Change," 265, is based on figures in E. Charlot and J. Dupaquier, "Mouvement annuel de la population de la Ville de Paris de 1670 à 1821," Annales de Demographie historique, (1967),512-513 from which Shorter calculated a ratio of enfants trouves (foundlings) per one hundred baptisms. It is perfectly clear that the institution of the reformed foundling hospital in 1690 meant a greatly increased number of foundlings in the next decade. See also, William Langer, "Checks on Population Growth: 17501850," Scientific American,(February 1972), 92-99. Langer's discussion of infanticide at the end of the eighteenth century suggests that births were registered before the baby died, whether of neglect by its mother or wet-nurse. Just as certain groups of women were more vulnerable to seduction and illegitimate motherhood, these same women were also more likely to be accused of infanticide because they could not hide their actions. McBride, citing Rene Bouton, L'Infanticide, etude morale et juridique (Paris, 1897), 171, notes that servants were the largest occupation of women to be accused of infanticide.

41. Fairchilds, citing La mendicite abolie dans la ville d'Aix par l'Hôpital general ou Maison de charite, an undated pamphlet which she dates from the late seventeenth century. 
42. Ford, 178.

43. Maurice Agulhon, Une Ville Ouvriere au temps du socialisme utopique. Toulon de 1815 a 1851 (Paris, the Hague, 1970), 99.

44. Pierre Pierrard, La vie ouvrière à Lille sous le second Empire, (Paris, 1965), 118-120. Both the Pierrard and Agulhon descriptions immediately bring to mind the situation in contemporary Latin America, described for Mexico by Oscar Lewis, Five Families (New York, 1959), for Argentina, by Gino Germani, "Inquiry into the Social Effects of Urbanization in a Working-Class Section of Greater Buenos Aires," in Philip Hauser, ed., Urbanization in Latin American (New York, 1961), 206-233, for Peru in conversations with Eleanor Shepherd and James Lang, both of whom lived and worked with the poor in that country. Shorter discusses the "culture of poverty" argument and allows that the propertyless condition of agricultural laborers and cottage and factory workers meant they did not need "to observe social rules calculated to preserve the custodial family intact through the years." Nevertheless, he concludes by insisting on "psychological changes.:. within the minds of individual workers as a result of exposure to marketplace values." "Capitalism, Culture and Sexuality," 345-348; 354; 355 .

45. Edith Thomas, Les Petroleuses (Paris, 1963), 20-23; Richard Cobb, "The Women of the Commune," in Second Identity. Essays on France and French History (London, 1969), 231. 
Parent-Duchatelet's figures on prostitution in Paris confirm this point. He also notes that common-law marriage was common among the Parisian working-class, Vol. I, 107.

46. A personal letter dated December 10, 1973 from Robert Wheaton to Charles Tilly stating a similar argument came to our attention several days after this paragraph was written. Shorter himself, "Sexual Revolution and Social Change," 257, sees the lack of property as crucial:

"[population growth] decapitated the authority of the family by creating so many children that parents had nothing to pass on to their extra-numerous offspring and hence no control over their behavior."

47. Shorter, "Sexual Revolution and Social Change," 253-255. Here Shorter recognizes the variable incidence of marriage as an important potential source of illegitimacy. See also John Knodel, "Law, Marriage and Illegitimacy in Nineteenth-Century Germany," Population Studies, 20 (1966-1967), 279-294. For the influence of the old and new Poor Laws on marriage and illegitimacy, see U.R.Q. Henriques, "Bastardy and the New Poor Law," Past and Present, 37 (1967), 103-129.

48. Régine Pernoud, "La vie de famille du Moyen Age à l'Ancien Regime," in Robert Prigent, ed., Renouveau des idees sur la famille, (Paris, 1954), 29.

49. E. P. Thompson, "The Moral Economy of the English Crowd in the Eighteenth Century," Past and Present, 50 (1971), $76-136$. 
50. Shorter, "Capitalism, Culture and Sexuality," 342; "Sexual Change and Illegitimacy," 247. Shorter, Knodel and Van de Walle, 390, acknowledge that cities were the place in which illegitimate fertility first rose, thus assigning some causal role to rural-urban migration.

51. Shorter, "Capitalism, Culture and sexuality," 342; E. A. Wrigley, Population and History (New York, 1969), 151-156 ff explores eighteenth century population growth and some of its social concomittants. Shorter accepts the initial importance of population growth in "Sexual Change and Illegitimacy," 249, as well as the connection of migration and increased illegitimacy and the end of the linkage of marriage and property settlement.

52. On improvident marriages, see Henriques, 111-112. The New Poor Law, Henriques shows, shifted the onus of illegitimacy from putative father to mother in hopes of reducing illegitimacy and ending improvident marriages, "even if it deprived the current generation of girls of being made 'honest women' and the current generation of children of a home." Braun, 59, also discusses what contemporaries called "beggar weddings" in the Zurich hinterland. Cf. Matti Sarmela, Reciprocity Systems of the Rural Society in the FinnishKarelian Culture Area with Special Reference to Social Intercourse of the Youth (Helsinki, 1969), a reference provided to us by shorter. Sarmela, 57, shows that a 1739 Swedish law applied to Finland tried to control the economic freedom of landless people (1739) while another 
law (1734) established marriage as well as betrothal as the official binding rite, 86. The temporal coincidence of these two laws is instructive and, in fact, fits our model.

53. The investigators associated with the Roussel committee of the French National Assembly in 1874 reported that women who worked outside the home were those who most often resorted to the use of wet-nurses. In areas where women practiced domestic industry, on the other hand, children were nursed at home and infant mortality was also lower. During the 1840's and 50's in France, the period of expansion of women's work in unskilled garment trades in cities, the wet-nurse "industry" boomed. Reformers sought to stop the practice by finding alternatives to poor women working outside the home, or by insisting that child-care facilities be available near where mothers worked. In 1837-38 it was suggested, for example, that the agencies which placed children with wet-nurses be transformed into agencies to distribute aid to poor families. Financial aid would make it possible to bring a nurse into the home or, better still, to keep the mother at home with her child. A bill involving this was introduced in 1842 and again in 1866, but never became law. The Loi Roussel of 1874 attempted only to regulate wet-nursing establishments. Annales de l'Assemblee Nationale, T. XXXII, 5 juin - 7 juillet, 1874. Annexe No. 2446 (Paris, 1874), annexe, 48-133. See especially pages 54, 59, 74, 84-5 (which 
points out that infant mortality is highest in regions with large cities in part because of the large numbers of working mothers), 98, 119-120.

54. John Knodel, "Two and a Half Centuries of Demographic History in a Bavarian Village," Population Studies, 24 (1970), 353-376.

55. J. A. Banks, Prosperity and Parenthood: A Study of Family planning among the Victorian Middle Classes (London, 1954). See also, Charles Tilly, "Population and Pedagogy in France," History of Education Quarterly (Summer, 1973), $113-128$.

56. Shorter, Knodel and Van de Walle, 393.

57. See the historical tables on labor force composition for France, England, Germany and Italy in T. Deldycke, et al, La Population active et sa structure for the proportionate decline in domestic service as a woman's occupation.

58. We wish to thank Kathryn Kish Sklar for communicating her letter (written jointly with Ellen Dubois) to us in advance of its publication in the American Historical Review. We also have discussed our argument with and received helpful criticism from Charles Tilly, Michael Hannigan, Lawrence Stone and Peter Laslett. 